Original Research Article

\title{
Knowledge, attitude and practices of antibiotic usage among the medical undergraduates of a tertiary care teaching hospital: an observational cross-sectional study
}

\author{
Padmanabha T. S. ${ }^{1}$, Nandini T. ${ }^{2}$, Manu G. ${ }^{1}$, Madhav K. Savkar ${ }^{1}$, Ravi Shankar M. ${ }^{1}$
}

\begin{abstract}
${ }^{1}$ Department of Pharmacology, Adichunchanagiri Institute of Medical Sciences, BG Nagara, Nagamangala Taluq, Mandya District, Karnataka, India, ${ }^{2}$ Department of Pharmacology, Sri Siddhartha Medical College, Tumkur, Karnataka, India
\end{abstract}

Received: 10 August 2016 Accepted: 15 September 2016

\section{*Correspondence to: Dr. Padmanabha TS, Email: padmanabhatsp @ gmail.com}

Copyright: (C) the author(s), publisher and licensee Medip Academy. This is an openaccess article distributed under the terms of the Creative Commons Attribution NonCommercial License, which permits unrestricted noncommercial use, distribution, and reproduction in any medium, provided the original work is properly cited.

\begin{abstract}
Background: Social aspect of antibiotic management forms a significant way to overcome the rapidly intensifying problem of antibiotic resistance. Medical students should not only be made aware of the current emerging health issues but also be directed towards rational antibiotics prescribing behavior as future medical practitioners. Aims and objective of the study was to assess the knowledge, attitude and practices (KAP) related to antibiotic usage in second year medical undergraduate students.

Methods: The study design was cross sectional, questionnaire based survey. The questionnaire was distributed to a 3rd term and 4th term medical students in their second year of MBBS, to know the KAP regarding antibiotic usage and was assessed by a five point Likert scale and few questions were of true and false type. The data was analyzed by using SPSS.

Results: Out of 162 students, $138(85.19 \%)$ participated in the study; 63 $(45.65 \%)$ were males and $75(54.35 \%)$ were females. $84.06 \%$ of the participants known that irrational and indiscriminate antimicrobial use leads to the emergence of resistance. 96.38\% agreed that Antibacterial resistance(ABR) was an important and a serious global public health issue and national problem. $71.01 \%$ of the respondents were aware that bacteria were not responsible for causing colds and flu. $86.23 \%$ said it can lead to more adverse drug reaction.

Conclusions: The present survey on antibiotic usage gives useful information about the knowledge, attitudes and practices of second year medical undergraduates, which may be utilized to plan suitable educational interventions that aim at improving the antimicrobial prescribing and use to maximize their effective and efficient use and minimize the development of resistance.
\end{abstract}

Keywords: Antibiotic use, Antimicrobial resistance, Attitude, Knowledge, Practice, Questionnaire

\section{INTRODUCTION}

Selman Waksman first used the word antibiotic as a noun in 1941 to describe any small molecule made by a microbe that antagonizes the growth of other microbes. ${ }^{1}$ In 2011, WHO set the theme of World Health Day as 'Combat Antimicrobial Resistance: No Action Today, No Cure Tomorrow'. ${ }^{2}$ The WHO, in 2012, has emphasized the importance of rational prescribing in the undergraduate medical curriculum. ${ }^{3}$
This shows a serious and global problem of antibiotic abuse and there is a growing consensus to urgently develop new strategies for prevention of resistance of bacteria to antibiotics. In recent years, an increasing number of researchers have focused their attention on antibiotic misuse, and follow with interest the knowledge, attitude and practice (KAP) towards antibiotics use of public. ${ }^{4,5}$ Medical students are future doctors for any society and they are the primary stakeholders in any health care system. ${ }^{6}$ Therefore, their beliefs and practices 
regarding antibiotic prescribing will have an impact on antibiotic resistance.

The major chunk of the problem persists in the developing countries. India tops in the irrational and indiscriminate use of antimicrobials. ${ }^{7}$ Being the country with high infectious disease burden antibiotics are the most widely and frequently prescribed drugs accounting for the alarming increase in Antimicrobial Resistance (AMR). ${ }^{8}$ The irrational prescription practices by clinicians are mainly governed by the "more drug better doctor" beliefs of patients. Free unchecked over the counter (OTC) availability of antibiotics for human, animal and industrial consumption, self-medication, lack of knowledge, unjustified demand for antibiotics prescription and unawareness regarding antibiotic resistance are other factors that add up to the current degrading situation. To curb this emerging horizon of AMR a national antibiotic policy was developed, national surveillance database for antibiotic use was established and national centre for disease control (NCDC) is designated as the focal point for AMR in the country.,10

Though these well-structured interventional strategies are still in infancy, it has started yielding positive changes at national and community level. However, something more specific and directed needs to be done at individual level that influences health related behaviour. While knowledge plays a significant role in providing an insight into the problems faced, it is the beliefs and attitude that matters most in directing the desired behavioural change. Ultimate aim of all these interventions is to bring out attitude and behavioural changes at the very grass-root level.

The current study will provide suitable data to frame a new curriculum program to acquire and equip our students to fight against Antibiotic Resistance. A strong foundation is of utmost importance for a durable construction hence we need to strengthen the base of the health care system by nipping the problem of resistance in the bud itself. Therefore, the present study was undertaken to assess the existing knowledge, attitude and practices of second year (third and fourth semester) MBBS students on antibiotics.

\section{METHODS}

This was a questionnaire based cross sectional study conducted among 162 medical Undergraduates during May 2016 to June 2016 at a tertiary care teaching hospital (AIMS, B.G Nagar, Karnataka) following approval from the Institutional Ethics committee. A questionnaire was used to assess knowledge, attitude and practice of antibiotic usage among $2^{\text {nd }}$ year $\left(3^{\text {rd }}\right.$ and $4^{\text {th }}$ term $)$ medical students.

$3^{\text {rd }}$ and $4^{\text {th }}$ term students who are present on the day of data collection, willing to participate were included in the study and those who were absent, not willing to participate or did not return the questionnaire within the stipulated time were excluded. A KAP questionnaire containing 13 questions (knowledge 04, attitude 05, and practice 04) was designed by modifying the earlier ones which were used by Eng JV et al and others. ${ }^{11-13}$

After briefing about the study, the KAP questionnaire was distributed to $2^{\text {nd }}$ year medical students during one of their pharmacology classes and was asked to complete the questionnaire anonymously. Informed consent was obtained from the participants, to utilize their data for research purposes. Quality control was maintained as per the standard protocol and Confidentiality was maintained. The participants' KAP was assessed by using true/false type and a Likert scale based question whose responses ranged from "strongly agree to "strongly disagree" and "always" to "never. Simple descriptive statistics was used to generate frequencies, percentages and proportions. SPSS version 17.0 was used to analyze the data.

\section{RESULTS}

Out of 162 students, $138(85.19 \%)$ participated in the study; $63(45.65 \%)$ were males and $75(54.35 \%)$ were females. The response rate was $85.19 \%$. The analysis was done using five point response options of the Likert scale for attitude and practice questionnaire and true or false type options for assessing knowledge. About $79.27 \%$ of the respondents agreed that an indiscriminate and injudicious use of antibiotics will lead to an ineffective treatment, increased adverse effects, emergence of bacterial resistance, increased hospital stay and an additional burden of medical costs to the patient.

Table 1: Questionnaire to assess knowledge.

\begin{tabular}{|llll|}
\hline 1. & \multicolumn{3}{c|}{ Knowledge questionnaire (true/false) } \\
\hline K1. & Indiscriminate use of & $\begin{array}{l}\text { True } \\
\text { antibiotics can lead to }\end{array}$ & $\begin{array}{l}\text { False } \\
(\%)\end{array}$ \\
\hline a) & Ineffective treatment & 79.71 & 20.29 \\
\hline b) & Increased Adverse effect & 86.23 & 13.77 \\
\hline c) & $\begin{array}{l}\text { Exacerbation or Prolongation } \\
\text { of illness }\end{array}$ & 64.49 & 35.51 \\
\hline d) & $\begin{array}{l}\text { Emergence of bacterial } \\
\text { resistance }\end{array}$ & 84.06 & 15.94 \\
\hline e) & $\begin{array}{l}\text { Additional burden of medical } \\
\text { cost to the patient }\end{array}$ & 81.88 & 18.12 \\
\hline K2. & $\begin{array}{l}\text { If taken too often, antibiotics } \\
\text { are less likely to work in the } \\
\text { future. }\end{array}$ & 87.68 & 12.32 \\
\hline K3. & $\begin{array}{l}\text { Bacteria are germs that cause } \\
\text { common cold and flu. }\end{array}$ & 28.99 & 71.01 \\
\hline K4. & $\begin{array}{l}\text { Antibiotic resistance is: an } \\
\text { important and serious public } \\
\text { health issue }\end{array}$ & $\begin{array}{l}\text { True } \\
(\%)\end{array}$ & $\begin{array}{l}\text { False } \\
(\%)\end{array}$ \\
\hline a) & Facing the world & 96.38 & 3.62 \\
\hline b) & In our country. & 96.38 & 3.623 \\
\hline c) & In our hospital. & 74.64 & 25.36 \\
\hline
\end{tabular}


A majority, $87.68 \%(n=121)$ respondents were aware that if antibiotics were taken too often, they are less likely to work in the future. Only $71.3 \%(n=98)$ of the respondents were aware that bacteria were not responsible for causing colds and flu, while the remaining $28.99 \%(n=40)$ were not knowledgeable about this fact. The Knowledge, attitudes and the self-reported practices of the students', which pertained to antibiotic use are examined on a Likert scale, the results of which are shown in the (Table 1), (Table 2) and (Table 3) respectively and the same in (Figure 1a,1b), (Figure 2), (Figure 3a, 3b) respectively.
A list of factors to be considered before prescribing an antibiotic were provided and the students were asked to rate them according to the importance which they felt that these factors deserved. About $86.23 \%$ of them gave importance to the adverse effect profile of the antibiotic. $65.22 \%$ of the participants felt that the following factors were important to be considered-the ability of the antibiotic to promote resistance. $70.29 \%$ participants felt that they consult a doctor before starting an antibiotic and $81.88 \%$ felt cost was an important factor which deserved consideration before the prescription of an antibiotic which otherwise leads to economic burden on patients.

Table 2: Questionnaire to assess attitude.

\begin{tabular}{|c|c|c|c|c|c|c|}
\hline 2. & Attitude Questionnaire (\%) & SA & $\mathbf{A}$ & UD & $\mathbf{D}$ & SD \\
\hline A1. & $\begin{array}{l}\text { When I have a cold, I should take antibiotics to prevent getting } \\
\text { a more serious illness. }\end{array}$ & 6.52 & 35.51 & 14.49 & 29.71 & 13.77 \\
\hline A2. & When I get fever, antibiotics help me to get better more quickly. & 15.94 & 41.30 & 22.46 & 14.49 & 5.78 \\
\hline A3. & $\begin{array}{l}\text { Whenever I take an antibiotic, I contribute to the development } \\
\text { of antibiotic resistance. }\end{array}$ & 21.74 & 43.48 & 22.46 & 10.87 & 1.45 \\
\hline A4. & $\begin{array}{l}\text { Skipping one or two doses does not contribute to the } \\
\text { development of antibiotic resistance. }\end{array}$ & 4.35 & 23.19 & 31.16 & 28.99 & 12.32 \\
\hline A5. & Antibiotics are safe drugs; hence they can be commonly used. & 4.35 & 31.16 & 23.19 & 26.09 & 15.22 \\
\hline
\end{tabular}

Rated Response: Strongly Agree (SA), Agree (A), Undecided (UD), Disagree (D), Strongly Disagree (SD)

Table 3: Questionnaire to assess medication practice.

\begin{tabular}{|lllllll|}
\hline 3. & Medication practice questionnaire $(\%)$ & & & \\
\hline P1. & $\begin{array}{l}\text { The doctor prescribes a course of antibiotic for you. After taking } 2-3 \\
\text { doses you start feeling better. }\end{array}$ & 1 & 2 & 3 & 5 \\
\hline a) & Do you stop taking the further treatment? & 9.42 & 21.01 & 28.26 & 16.67 & 24.64 \\
\hline b) & Do you save the remaining antibiotics for the next time you get sick? & 10.14 & 18.12 & 18.84 & 13.04 & 39.86 \\
\hline c) & Do you discard the remaining, leftover medication? & 11.59 & 10.87 & 22.46 & 19.57 & 35.51 \\
\hline d) & $\begin{array}{l}\text { Do you give the leftover antibiotics to your friend/roommate if they } \\
\text { get sick? }\end{array}$ & 12.32 & 21.74 & 28.99 & 10.87 & 26.09 \\
\hline e) & Do you complete the full course of treatment & 42.75 & 29.71 & 18.84 & 3.62 & 5.072 \\
\hline P2. & Do you consult a doctor before starting an antibiotic? & 39.86 & 30.43 & 19.57 & 5.79 & 4.35 \\
\hline P3. & Do you check the expiry date of the antibiotic before using it? & 80.43 & 5.79 & 10.14 & 1.45 & 2.17 \\
\hline P4. & $\begin{array}{l}\text { Do you prefer to take an antibiotic when you have cough and sore } \\
\text { throat? }\end{array}$ & 8.69 & 20.29 & 29.71 & 18.84 & 22.46 \\
\hline
\end{tabular}

Rated response: 1- Always, 2- Usually, 3- Sometimes, 4- Seldom, 5- Never

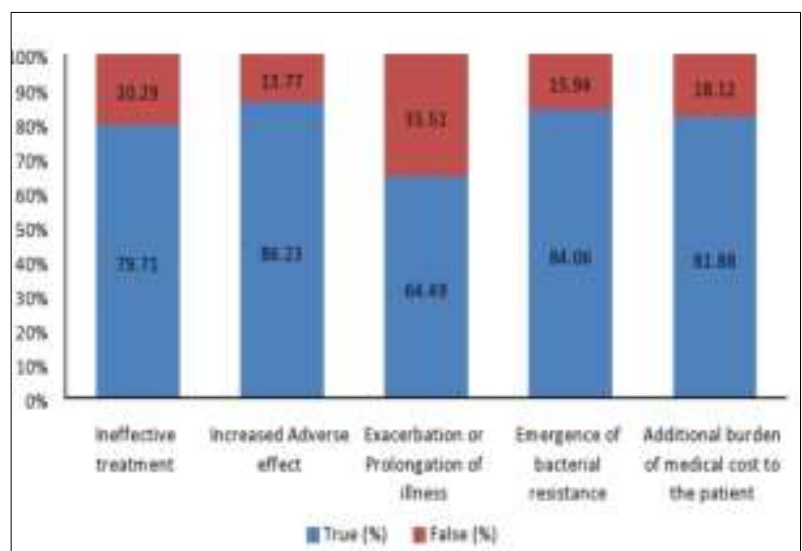

Figure 1a: K1- indiscriminate use of antibiotics.

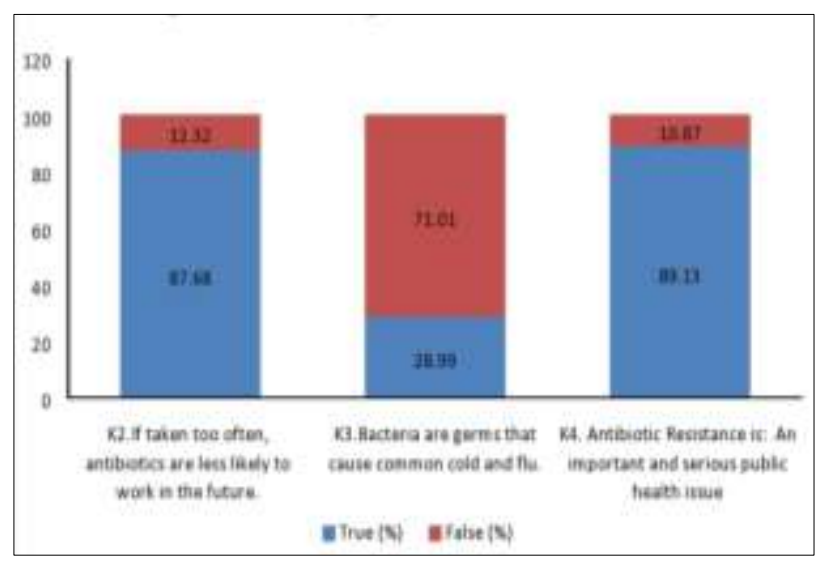

Figure 1b: Knowledge questionnaire- K2, K3, K4. 


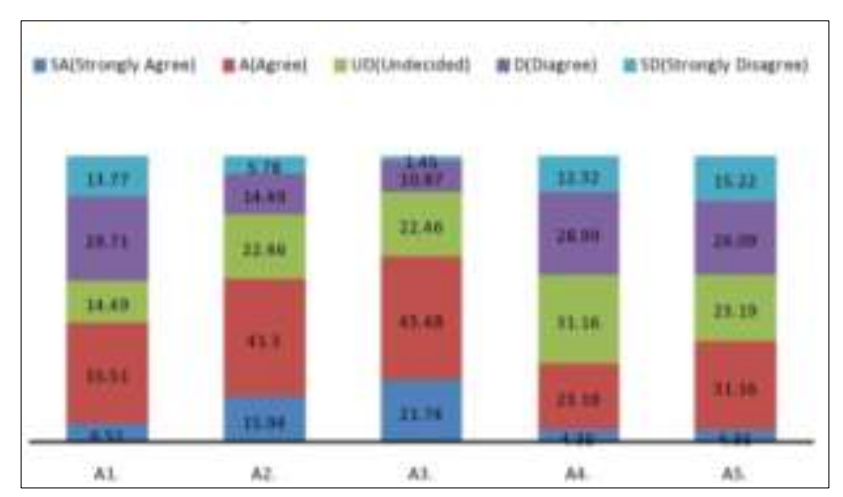

Figure 2: Attitude questionnaire (\%).

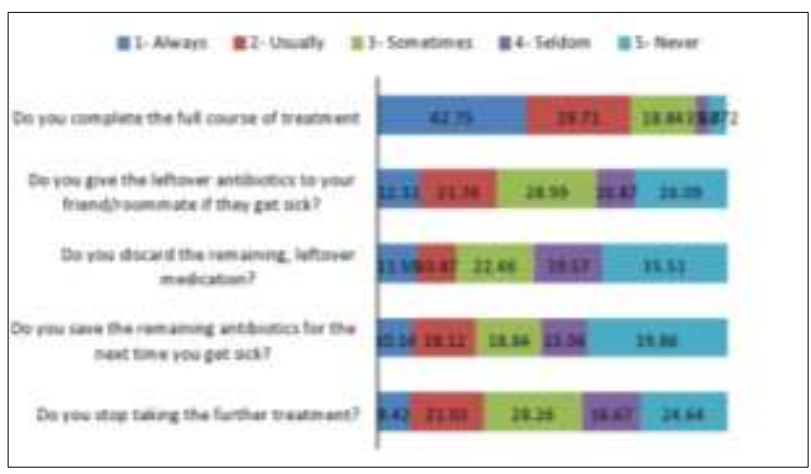

Figure 3a: P1- medication practice questionnaire (\%).

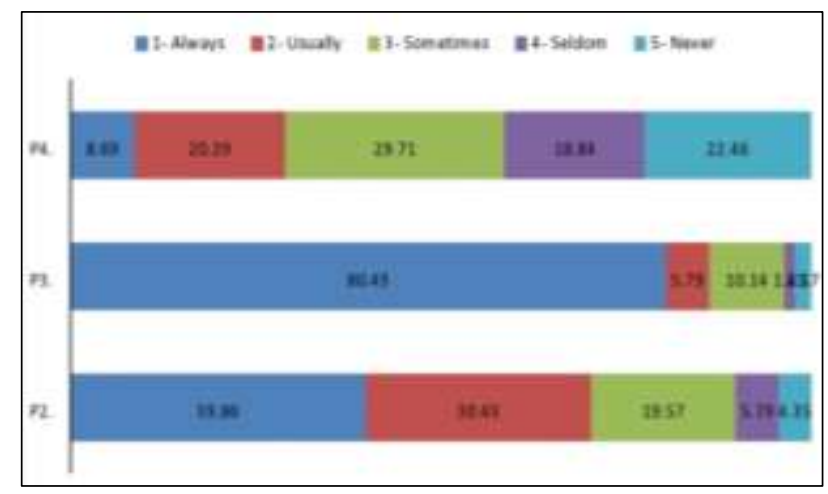

Figure 3b: P2, P3, P4-medication practice questionnaire (\%).

\section{DISCUSSION}

In our study most of them were aware of worldwide and national level problem of antimicrobial resistance, but at their own hospital, the antibiotic resistance was not considered to be a serious issue. A similar response was noted in previous studies where most of the participants did not give importance with the prevalence of the antibiotic resistance at their own institution. ${ }^{14-17}$ Education interventions using clinical problems which depicts the hazardous effects of antibiotic resistance, can be used to improve as well as make them alert on present and future consequences, which encourages the correct usage of antibiotics by avoiding the resistance conquering the whole world. ${ }^{16}$

The attitude of the students with regards to antibiotic use was found to be not very serious and was very much casual in their approach towards on usage of it. $42.03 \%$ of them reported that antibiotics should be taken on developing a cold to avoid serious illness and $57.24 \%$ of them believed that taking antibiotics on having a cold/fever made them feel better more quickly. Similar reports were seen in another study. ${ }^{17}$

$35.51 \%$ participants believed that antibiotics were safe drugs and hence, they could be commonly used; and $41.31 \%$ not safe and $28.99 \%$ were not knowledgeable of the fact that bacteria were not responsible for causing cold and flu which was slightly higher than Afzal et al (15.5\% and $22.7 \%$ respectively) study. Previous studies have shown that about $60 \%$ and more of their participants believed that antibiotics should be prescribed during cold of viral etiology. ${ }^{18}$ Such wrong and blind beliefs may lead to inappropriate antibiotic consumption, which in turn result in the bacterial resistance because of irrational approach. ${ }^{19}$ The common cold is a viral illness for which the etiology can be shown in most cases. i.e., Rhinovirus. Bacterial co-infections are very rare. Antibiotic treatment is not necessary in otherwise healthy young adults with common colds. ${ }^{20}$ In the present study, students behaviour with regards to antibiotic use were found to be satisfactory and were aware of the misuse of antibiotics, in spite of all these wrong belief and practices among few participants.

Previous studies have shown high rates of self-medication (35\%) amongst medical students with respect to antibiotics. $^{21}$ Our study showed, a majority (>70\%) always consulted a doctor before starting on an antibiotic and always completed the full course of the prescribed treatment.

The principle causes of the emergence and the dissemination of resistant organisms is failure to implement policies and programs in preventing infections as well failure to follow the antimicrobial usage guidelines strictly. ${ }^{9,22}$

Interactive learning between pharmacology and microbiology helps in rational antimicrobial prescribing behaviour with infection control. Since antibiotic resistance among pathogenic microorganisms is a matter of worldwide concern, the prescribers should know the microorganism sensitivity pattern before prescribing it. ${ }^{23}$

Simple measures like hand washing in the control of resistance should be encouraged and its practice should be started at an earlier stage of the medical profession. ${ }^{16}$ In our study the students were aware and concerned about the individual patient's benefits and harms, the dangerous consequences of indiscriminate antibiotic use. 
Small group exercises that facilitate the students in practicing patient education skills, proper use of antibiotics, should form an important part of the students' curriculum, which should also aim to change the behaviour and to improve the patient outcomes along with the knowledge. ${ }^{23}$

The students should be made aware of these important facts and a sense of responsibility should be nurtured, that as prescribers, they are not only responsible for the benefit and the welfare of their patients but also for the society at large. Outcome-based education for educating the students about antibiotics, maximize their effective and efficient use and minimize the development of resistance as a prescriber. ${ }^{21}$ The principles of the protocol development for antibiotic use in health care facilities should form an integral part of the undergraduate teaching. ${ }^{22}$

Limitations of the study included less sample size from a single private teaching hospital and exclusion of 3rd year, 4th year medical students and interns who will have a better knowledge compared to their juniors as they are more exposed to clinical knowledge and bed side clinics.

\section{CONCLUSION}

The present study on antibiotic usage gives useful information about the knowledge, attitudes and the practices of second year medical undergraduates, which may be utilized to plan suitable educational interventions/small group exercises that aim at improving the efficient antimicrobial prescribing, proper use (adherence) by the patients in order to minimize the development of drug resistance.

Funding: No funding sources

Conflict of interest: None declared

Ethical approval: The study was approved by the Institutional Ethics Committee

\section{REFERENCES}

1. Clardy J, Fischbach MA, Currie CR. The natural history of antibiotics. Curr Biol. 2009;19(11):437-41.

2. World Health Day 2011-Antibiotic resistance: No action today, no cure tomorrow. Available at http://www.who.int/mediacentre/news/statements/20 11/whd_20110407/en/index.htm. Accessed 12 July 2016.

3. World Health Organization. The evolving threat of antimicrobial resistance: options for action. Geneva: World Health Organization; 2012. Available at: http://apps.who.int/iris/bitstream/10665/44812/ 1/9789241503181_eng.pdf. Accessed November 10, 2015.

4. Andre M, Vernby A, Berg J, Lundborg CS. A survey of public knowledge and awareness related to antibiotic use and resistance in Sweden. J Antimicrob Chemother. 2010;65(6):1292-6.
5. You JH, Yau B, Choi KC, Chau CT, Huang QR, Lee SS. Public knowledge, attitudes and behavior on antibiotic use: a telephone survey in Hong Kong. Infection. 2008;36(2):153-7.

6. Harakeh S, Almatrafi M, Ungapen H. Perceptions of medical students towards antibiotic prescribing for upper respiratory tract infections in Saudi Arabia. BMJ Open Respir Res. 2015;2:e000078.

7. Kumar SG, Adithan C, Harish BN, Sujatha S, Roy G, Malini A. Antimicrobial resistance in India: a review. J Nat Sci Biol Med. 2013;4:286-9.

8. World health organization. Prevention and containment of antimicrobial resistance. Available at http://www.ino.searo.who.int/LinkFiles/Other_Conte nt_WHD11-Seminar_Presentation-WRpdf. Accessed 15 February 2016.

9. World health organization. Prevention and containment of antimicrobial resistance. Available at http://www.searo.who.int/entity/antimicrobial_resista nce/sea_cd_273.pdf?ua=1. Accessed 12 July 2016.

10. Directorate general of health service. National policy for containment of antimicrobial resistance India. Available http://www.ncdc.gov.in/writereaddata/linkimages/am r_policy1600931343.pdf. Accessed 12 July 2016.

11. Eng JV. Consumer attitudes and use of antibiotics. Emerging Infectious Diseases. 2003;9(9):1128-35.

12. Chen C. Behavior, attitudes and knowledge about antibiotic usage among residents of Changhua, Taiwan. J Microbiol Immunol Infect. 2005;38:53-9.

13. Hsiao FY, Lee JA, Huang WF, Chen SM, Chen HY. Survey of medication knowledge and behaviors among college students in Taiwan. Am J Pharm Edu. 2006;70(2):30.

14. Thriemer K. Antibiotic prescribing in DR Congo: a knowledge, attitude and practice survey among medical doctors and students. PLoS One. 2013;8(2):e55495.

15. Sellman JS, Decarolis D, Schullo-Feulner A, Nelson $\mathrm{DB}$, Filice GA. Information resources used in antimicrobial prescribing. J Am Med Inform Assoc. 2004;11:281-4.

16. Wester CW, Durairaj L, Evans AT, Schwartz DN, Husain S, Martinez E. Antibiotic Resistance - A Survey of Physician Perceptions. Arch Intern Med. 2002;162:2210-6.

17. Khan A, Banu G, Reshma KK. Antibiotic resistance and usage: a survey on the knowledge, attitude, perceptions and practices among the medical students of a southern Indian Teaching Hospital. J Clin Diag Res. 2013;7(8):1613-6.

18. Azevedo MM, Pinheiro C, Yaphe J, Baltazar F. Portuguese students' knowledge of antibiotics: a cross-sectional study of secondary school and university students in Braga. BMC Public Health. 2009;9:359.

19. Steinberg I. Clinical choices of antibiotics: judging judicious use. The Am J Managed Care. 2000;6(23):S1178-88. 
20. Mäkelä MJ, Puhakka T, Ruuskanen O, Leinonen M, Saikku P, Kimpimäki M, et al. Viruses and bacteria in the etiology of the common cold. J Clin Microbiol. 1998;36(2);539-42.

21. Zafar SN, Syed R, Waqar S, Zubairi AJ, Vaqar T, Shaikh $\mathrm{M}$ et al. Self-medication amongst university students of Karachi: Prevalence, knowledge and attitudes. JPMA. 2008,58:214-7.

22. Nathwani D, Davey P. Antibiotic prescribing-are there lessons for physicians? J Med. 1999;92:5:28792 .
23. Davey P, Garner S. Professional education on antimicrobial prescribing: a report from the Specialist Advisory Committee on Antimicrobial Resistance (SACAR) Professional Education Subgroup. J Antimicrobial Chemotherapy. 2007;60(1):i27-32.

Cite this article as: Padmanabha TS, Nandini T, Manu G, Savkar MK, Shankar RM. Knowledge, attitude and practices of antibiotic usage among the medical undergraduates of a tertiary care teaching hospital: an observational cross-sectional study. Int $\mathbf{J}$ Basic Clin Pharmacol 2016;5:2432-7. 